Revue Française de Civilisation Britannique

\title{
A Legal Maternal Wall? No Revolution in Motherhood for Women Lawyers in England
}

Un «mur de la maternité" dans les professions juridiques? Pas de révolution de la maternité pour les avocates en Angleterre

\section{Alexandrine Guyard-Nedelec}

\section{(2penEdition}

Journals

Édition électronique

URL : http://journals.openedition.org/rfcb/1859

DOI : $10.4000 /$ rfcb.1859

ISSN : 2429-4373

Éditeur

CRECIB - Centre de recherche et d'études en civilisation britannique

\section{Référence électronique}

Alexandrine Guyard-Nedelec, « A Legal Maternal Wall? No Revolution in Motherhood for Women Lawyers in England », Revue Française de Civilisation Britannique [En ligne], XXIII-1 | 2018, mis en ligne le 20 mars 2018, consulté le 23 août 2020. URL : http://journals.openedition.org/rfcb/1859 ; DOI : https://doi.org/10.4000/rfcb.1859

Ce document a été généré automatiquement le 23 août 2020.

\section{c) (1)}

Revue française de civilisation britannique est mis à disposition selon les termes de la licence Creative Commons Attribution - Pas d'Utilisation Commerciale - Pas de Modification 4.0 International. 


\section{A Legal Maternal Wall? No Revolution in Motherhood for Women Lawyers in England}

Un «mur de la maternité » dans les professions juridiques? Pas de révolution de la maternité pour les avocates en Angleterre

Alexandrine Guyard-Nedelec

\section{Introduction}

1 The concept of a "maternal wall", developed by law professor Joan Williams in the United-States in the $1990 \mathrm{~s},{ }^{1}$ refers to a form of discrimination based on family responsibilities. It is a pattern of bias and stereotyping that affects mothers as opposed to women in general. ${ }^{2}$ This approach looks at the pay gap and other short- and longterm impacts of pregnancy, maternity and motherhood in terms of career and discrimination. The concept may be seen as a pendant to the more well-known glass ceiling. In the United-States, the concept quickly gained traction in the press ${ }^{3}$ and since the early 2000s court cases have tended to show that this form of discrimination was finally becoming recognized as illegal. ${ }^{4}$

2 Surprisingly, the concept has received little attention in Europe. Applied to the English legal profession, it sheds light on the testimonies of women barristers and solicitors who, when asked, have often said they believed there was no sex discrimination in their profession, but that discrimination on the grounds of maternity, by contrast, was rife. This article thus presents a case study focusing on gender equality issues in the legal profession in England and Wales that underlines the specific weight of motherhood in the slow transformation of women's roles vis-à-vis those of men in the professional sphere.

3 The aim of such a focus is not to exalt motherhood as women's most important condition in the spirit of what historians have called 'maternalism'. ${ }^{5}$ It is, however, to 
take seriously the fact that women remain the expected primary carers for children in spite of feminist struggles for gender equality in the domestic sphere. Indeed, reproductive power has been claimed by some as the main, if not the only factor leading to male domination and patriarchy. Anthropologist Françoise Héritier sees it as central in what she calls the "differential valence of the sexes". ${ }^{6}$

Acknowledging the specific issues facing women as (real or potential) mothers, while positing that this identity should not be seen as part and parcel of female identity but constructed as an intersectional facet of identity may help reconcile opposing feminist views on maternity and motherhood. It may also help overcome the maternal wall by lifting the veil on the intangible, surreptitious way it operates.

5 That being said, not all women are mothers: in the UK, it is estimated that around $20 \%$ of women remain child-free (a level which is not historically unprecedented). ${ }^{7}$ Furthermore, the most educated women are among the most likely never to have a child. Unlike in some other European countries (such as the Netherlands or Norway) or in the United-States, ${ }^{8}$ educational differentials in childlessness are not narrowing over time; they are even increasing slightly. Today in the UK, for a wide range of reasons (not wanting children, postponing, not meeting the right person, health reasons and so on) tertiary-educated women are approximately twice as likely as women with low levels of education to remain child-free. ${ }^{9}$ In the light of these figures, and in order to focus on gender equality issues in the law, specific attention needs to be explicitly given to the hurdles faced by women because of their maternal status - yet without identifying all women with mothers. For instance, in their latest study of women in the labour market (2013), the Office for National Statistics have identified that in the younger age groups of $16-24$ and $25-29$, the top $10 \%$ of earners were relatively evenly split between men and women, but that "the greatest fall in the percentage of the top 10\% of earners that were women was between the 25-29 and 30-34 age groups, coinciding with women having children in their late twenties. Therefore, the percentage of women in the highest paid reduces after the average age that women tend to give birth to their first child". ${ }^{10}$ Thus, assimilating these forms of discrimination to sex discrimination or, in other words, those forms of inequality to sex inequalities would not be true to the experiences lived either by women who have children or by those who do not.

In the legal profession, the hours, the specific timetable constraints (linked to court hearings), the role of clerks in chambers, etc., all contribute to making women lawyers subordinates. The prominence of maternity and motherhood, playing a key part in this subordination, was seen to be flagrant in interviews carried out in 2007-08 for the author's PhD fieldwork ${ }^{11}$ with women lawyers and judges, research which aimed at testing a number of hypotheses and gaining further insight into the dynamics of identity and discrimination. Recent studies on the legal profession corroborate these findings and underline the resilience of these patterns. ${ }^{12}$

7 In its first part, the article presents an overview of the legislative framework and practices in the profession. Then, by relying on examples derived from the fieldwork as well as the literature, it insists on juggling family and work in the legal profession as illustrations of the maternal wall. It aims at showing that discrimination on the grounds of maternity should be constructed as a form of intersectional discrimination. Intersectionality primarily stems from African-American feminist research, as a reaction to the fact that the interaction of sexism and racism was neither acknowledged by equality legislation nor identified by scholars. First coined by law 
professor Kimberle Crenshaw, ${ }^{13}$ the concept has received a tremendous amount of attention over the past ten years. ${ }^{14}$ In the present article, intersectionality is predominantly deployed in its relation to multifaceted identities but the author also draws on its ability to refer to systemic structural forces that shape societies.

Indeed, even though it is intricately tied to sex and gender, to reduce discrimination on the grounds of maternity to a form of sex discrimination might easily amount to an essentialist analysis. ${ }^{15}$ This form of discrimination partly explains the slower progression of women on the professional ladder, their relative confinement to certain areas of law and, consequently, the small proportion they account for in the senior judiciary, in spite of the fact that women now outnumber men among law students, ${ }^{16}$ achieve better academic results on the whole ${ }^{17}$ and have made up around $50 \%$ of the profession at entry level for about twenty years. ${ }^{18}$ This situation undermines the trickle-up argument that is often put forward when trying to justify the lack of women in the upper echelons.

\section{Overview: legislative framework and practices in the profession}

This section aims to offer an overview of the British legislation and regulations that frame maternity and motherhood issues in the field of employment, in particular maternity leave and flexible working arrangements. It focuses on the input of the regulatory bodies of the legal profession, namely the Bar Council and Law Society, and contrasts the measures they have gradually introduced with the development of factory-like working patterns that appear to undermine recent efforts at more equality in the workplace.

In the UK, The Sex Discrimination Act 1975 specifically prohibited discrimination on the grounds of pregnancy or maternity leave. Since October 2010, this type of pregnancy and maternity discrimination has been unlawful under the Equality Act; ${ }^{19}$ it qualifies as automatic discrimination without the need to provide a male comparator, whereas such a comparator (actual or hypothetical) is used in other sex discrimination cases involving women, to test whether a man would have been treated more favourably in similar circumstances..$^{20}$ The current protection exists from conception to the end of statutory maternity leave (the 'protected period'). The Equality Act's provisions for pregnancy and maternity cover all areas of employment, including, but not limited to, recruitment, promotion, training and redundancy selection. The Employment Rights Act 1996 and the Maternity and Parental Leave Regulations 1999 give employees (but not other workers) additional protection. This legislation makes dismissal automatically unfair if it is due to an employee's pregnancy or maternity leave. Subjecting a woman to any other detriment due to her pregnancy or maternity leave (or because of illness suffered by her as a result of her pregnancy) is also unlawful.

11 Statutory maternity leave in the UK is 52 weeks, made up of 26 weeks of "Ordinary Maternity Leave" and 26 weeks of "Additional Maternity Leave". ${ }^{21}$ Women must take at least two weeks' leave after their baby is born. In addition, occupational pension schemes are now all deemed to include a maternity equality rule so that women are not treated unfavourably. There are differences depending on the collective agreements and specific measures taken by employers. Despite this framework however, 
discrimination based on the potential to become pregnant was reported a number of times in the interviews carried out by the author. This is linked to statistical discrimination, as theorised by Edmund Phelps: ${ }^{22}$

[...] the employer [who has no distaste for hiring and working alongside blacks and women and] who seeks to maximise expected profit will discriminate against blacks or women if he believes them to be less qualified, reliable, long-term, etc. on the average than whites and males.

In terms of the regulations that apply to the legal profession more specifically, the Bar Council, which is the representative body for barristers, encourages chambers to have a written policy addressing maternity, paternity and parental leave, providing definitions and including provisions on pre-departure and pre-return questions. They offer guidance with a detailed checklist mentioning for instance "What facilities does Chambers offer for maternity returners i.e. refrigeration for expressed milk, information on the nearest childcare providers, can Chambers obtain a discount for members, etc.". ${ }^{23}$ The Bar Council has also produced a "Family Career Breaks Advice Pack" ${ }^{4}$ and holds "Family Career Breaks" events annually. The role played by the Bar Council and Bar Standards Board (the regulatory body of the branch) is key, as most barristers are self-employed (those who work in sets of chambers), and remain outside the scope of the legislation regarding these issues. They have, for example, standardized the practice of allowing women six months free of rent for maternity leave since 2004 and produced Equality Rules that came into force in 2012, accompanied by regular monitoring. ${ }^{25}$ Such policies greatly contribute to retaining women in the profession ${ }^{26}$ but they can still generate tensions in chambers. One of the interviewees thus explained:

It's all very well for everyone to say 'everybody should be entitled to lots of maternity leave and reduced fees', but it's the rest of us who then have to subsidise them. So there is that, and the other thing is, if you have a diary of practitioners, let's say one team, $1 / 3$ of them are on maternity leave at any time. It makes it quite difficult for the clerk to accommodate them only working part-time; and then for the rest of us - in fact I think I probably benefited from that because, as somebody who doesn't have children, when the other members of my team have gone off and had children, I'm the one that gets the bigger cases; so in fact I think it's worked in my favour. [Interview 4]

13 Her account unveils the controversy around maternity and motherhood issues: at first the barrister seems to complain that she has to subsidise, in a way, what she perceives as advantages given to mothers but then acknowledges that from a professional point of view she has often benefitted from such periods of leave by being given bigger cases. The complexity of the issue derives from the conflict between the theoretical and the practical level but also, it seems, between the individual and the collective level. It is easy to argue collectively that the workplace should be adjusted in order to help mothers, but the practitioners directly confronted with that type of situation may deem the effort it might require from individuals too burdensome. Another characteristic of the barristers' branch of the profession is the gap that exists between different sets of chambers. The following account exemplifies this gap more convincingly than many statistics:

The last chambers I was at, [...] I think we had a baby born every month, we had hundreds of babies, but we didn't lose a single woman in 17 years. They all came back, and they all resumed their practice, either at a part-time level or a full-time level, as they wished, and when they wanted to, they got back into the work full time. I think that was exceptional. This chambers, they have taken on women, there's no doubt about that, [...] but all the women have left, around maternity 
leave. We have to ask 'Well why is that, what went wrong?' [...] It may be coincidence, [...] but I have no evidence that there is no obstruction. But nonetheless, for me it's more than a coincidence that all these women have gone. [Interview 6] confirmed this trend. It underlined a very marked difference in the views, perceptions and expectations of younger participants from Generation Y (born after 1980). The report emphasized the high exit rate from city firms of talented men and women who found the profession at that level incompatible with their expectations of work/life balance. However, in spite of almost universal rhetorical commitment to diversity and inclusion across the legal profession in England and Wales, the recession has impacted equality and diversity and makes it more difficult to ask for flexible working as women often contort in order to keep their jobs. ${ }^{31}$ Sommerlad's latest articles evidence a deepening of those trends (intensification of work and heightened significance of client care in particular), which appear to be having a particularly adverse impact on women's working conditions. ${ }^{32}$

Indeed, the issue of flexible working is of great importance for women in the profession. Recent research carried out by Margaret Thornton in Australian law firms hints at the stigmatisation of those seeking to work flexibly, which, among other drawbacks, entrenches the masculinist identity of the ideal lawyer. ${ }^{33}$ The way she 
theorises the subsequent pathologisation of mothers ties in with the concept of maternal wall, illustrated below.

\section{Juggling family and work in the legal profession: illustrations of the maternal wall}

19 As has been widely identified by prior research, juggling a career and family life is far from easy and may be even harder for professional women, who tend to see their work as a primary role. ${ }^{34}$ Indeed, the professions involve a long period of studying and a high level of commitment to work. This section therefore aims at highlighting some of the social expectations around motherhood that often conflict with the work practices of the legal profession, notably in terms of hours. Combined with the confinement of women to some areas of the law, these frictions lead to numerous dropouts.

The tensions that may arise in the frail balance between the different roles are most of the time due to down-to-earth aspects, in particular childcare, not only in the long run but also sporadically, when children are ill for instance:

[A set of chambers] is a business, and each member of the chambers generates an income, for that chambers. Should your child be ill, you can't go to court - you may not be able to turn up on a case, you may cause solicitors a whole load of hassle in order to get someone there who won't know the case, [...] So a solicitor won't use you again, if you let them down, they will not use you at all, because you are a risk, because again, they are also a business, they want somebody reliable, you then lose, lose funds for chambers, and that's just one example, and it goes without saying in our culture [...] as soon as a child is ill, or hurt, the first person they want is Mom. I know my children do. [nterview 2]

Whether or not children want their mother or whether the interviewee had absorbed this social norm and made it hers, in the vast majority of cases, it is still the mother, and not the father, who deals with childcare issues, because of the specific status conferred on mothers as primary caretakers. Most interestingly, this specific status has been conceptualised by Cecilia Ridgeway and Shelley Correll, as analytically distinct from the female gender, ${ }^{35}$ and this is particularly relevant in an intersectional perspective as it refrains from equating women and mothers, without denying the intermingled dimensions of womanhood and motherhood. ${ }^{36}$ The two sociologists use expectation states theory, ${ }^{37}$ to try and account for inequalities. According to them, gender and motherhood are external status characteristics that are imposed by social beliefs and that come together with performance expectations. ${ }^{38}$ They conclude that motherhood is a specific status that has a direct negative impact in the workplace because the normative imperatives linked to motherhood conflict with those that apply to a committed, ideal-type worker. This conflict leads to the build-up of an imperceptible maternal wall. ${ }^{39}$ Such conclusions echo the life experiences reported by interviewees, for instance a solicitor who showed how motherhood had modified her managers' expectations:

Because I was a mother, I felt as though they didn't want to stress me, for instance doing research. [...] I kept telling them that I could do - they had a lot of work to be done, but they didn't want to delegate. [...] but that was the very reason that I was there: to learn. And the only way to learn is if you delegate some of the work to me. I was a graduate, and I was quite capable of doing research. Anyway, there was a change of the management, the manager [...] handed over to a female director, and 
she actually gave me research work to do, and it made a big difference. [Interview 1] on outsider status and professional socialization in the solicitors' profession. A woman who wanted to qualify as a solicitor as a mature student noted that older women - who have often had children - have become used to doing caring work and that it is more difficult for them to cultivate the kind of arrogance that's expected from a lawyer, to give their voice and body language the self-confidence and the certainty that are essential to the authority of the profession..$^{40}$ The gap between the opposing imperative normatives is such that it generates further hurdles for women who want to join the profession later in life. ${ }^{41}$ Another interviewee, who was heading a department in a law firm, observed that this gap could be deconstructed as superficial, if motherhood stopped being so undervalued. Drawing on a long-standing feminist insight, she listed a whole "personal skills-set that maternity brings", including "a capacity to plan, to organize, to look ahead, to manage their resources, to manage a project" that could be valued in the workplace but is often disregarded [Interview 13].

If expectations and social roles play a major part in structuring behaviour and career patterns, other day-to-day constraints also contribute to the existence of the maternal wall. In the legal profession, one of these constraints is the hours. The situation differs for solicitors and for barristers. As far as solicitors are concerned, much of the problem, as identified notably by Sommerlad, derives from the macho glorification of workaholism and long hours, which contribute to placing women on the side of deviance and weakness because of their responsibilities as caretakers. ${ }^{42}$ The situation of barristers is different, as their timetable is very much linked to the court's, which generates further complication when asking for flexible working. One of the difficulties in juggling a barrister's work with family life is the unpredictability: when they are instructed by a solicitor, they do not know how long the case is going to be, whether it is going to come in early, late, or be rescheduled at a different time. Besides, at a certain level of seniority, cases may often be listed for five days in a row (Monday to Friday). If a barrister has their Friday off as a flexible working arrangement, they cannot take up these cases and will only be able "to pick up the rubbish small ones" [Interview 4]. Another solution is doing a paperwork practice and being in chambers most of the time, but in both situations the barrister's practice will suffer. The fee structure also impacts the actual possibility of working part time, as barristers give a percentage of their earnings to chambers. Those working part time do not earn as much and thus do not give as much percentage, thereby reducing the incentive to arrange for flexible working:

I know lots of chambers where the senior members think 'well why should we be subsidising the part-timers?' Because they're just as difficult to clerk, maybe even harder to clerk, so more effort is going in by the clerks to arrange their diaries, but in fact they're not bringing in as much income. [Interview 4]

Such considerations may provide some explanation for another facet of the maternal wall, i.e. the relative confinement of women to certain areas of law, or their relative exclusion from others, to put it differently, notably criminal law. In this area in 
particular, it is not rare that cases last for weeks, sometimes for months, and may require spending prolonged periods of time in another town.

The role of clerks, hinted at by the interviewee cited above, is linked to the timetable but expands much further. Clerks are the legal assistants who interact with solicitors, distribute the caseload to the different barristers in chambers, manage their diaries, and often keep the accounts. A number of practices inherited from past generations of clerks still operate and a chambers' manager interviewed in London gave insights into the role they can play for women's career in particular [Interview 6]. In spite of the existence of an Institute of Barrister's Clerks providing training, co-optation often prevails (from father to son or uncle to nephew) and it has remained a very maledominated branch. As of May 2000 (latest available figures), 74\% of IBC members were men and $26 \%$ women. ${ }^{43}$ Sexism long prevailed in the traditional way clerks used to work, sometimes aiming more at improving their own situation (financially or other) than that of others. And it was not always advantageous to favour female barristers rather than male, as the latter's career suffered fewer interruptions. Fixed salaries have been introduced in most sets, but clerks used to earn a percentage of the barrister's fees and the power relationship was often very complex. Younger clerks are better trained, familiarised with sales techniques and, perhaps even more importantly, with diversity and equality issues; their renewal can only be good for women, and for mothers in particular, as is suggested by the following comment:

Women at the Bar, in large numbers, is a relatively recent thing; you still hear things like 'Well, she just didn't do it the way that I expected', and what they really say is 'She didn't do it like a man'. They [the clerks] don't accept that there are different styles, different approaches, that clients want different approaches. [Interview 6]

Several studies have tried to understand the reason behind dropouts, and they highlight the key role of maternity and motherhood: family responsibilities are the most frequent reason why women do not renew their practising certificate, whereas for men it is generally due to anticipated retirement. ${ }^{44}$ Indeed, the difficulties experienced with part-time work, with juggling family and work often lead to career changes - from a mere change of specialism to the decision to work in a completely different sector or sometimes, to stop working altogether..$^{45}$

This pessimistic view of a patriarchal profession is further supported by a 2004 lawsuit, Siân Heard \& Fellows $v$ Sinclair Roche \& Temperley. ${ }^{46}$ Lawsuits opposing lawyers to their employers on the grounds of discrimination are uncommon or at least seldom go public. Law firms and chambers are well aware of the risks at stake, both in legal terms and for their reputation, thus these cases often settle out of court. ${ }^{47}$ In this case, Ms Heard and Ms Fellows, the claimants, decided to sue their employers because of their lack of progression in the law firm and the unfavourable treatment they had been subjected to (linked to maternity leave and requests to work part time, in particular). The Employment Tribunal openly described the culture of the firm as "discriminatory" and held that the claimants had never been given the same opportunities as their male counterparts to achieve the level of billings that was necessary to achieve full equity partnership. The tribunal's decision sheds light on the long-term effects of maternity leave when no form of compensation is introduced, and illustrates the vertical segregation which is one aspect of the maternal wall - especially for mothers who work part time, as well as their confinement to certain types of cases. Both claimants were 
awarded between $£ 400,000$ and $£ 500,000$, a large sum of money, which shows the courts and tribunals do take these cases seriously.

The details of the case deliver an interesting perspective on the difficulty of separating sex discrimination and maternity and pregnancy discrimination, and help us to understand how their combination amounts to intersectional discrimination. Indeed, what defines intersectional discrimination is the impossibility of separating the different grounds, which are intermingled in the manner of a "marble cake". ${ }^{48}$

\section{Conclusion}

Resorting to the concept of maternal wall to describe these situations of discrimination highlights the long-term negative effects of motherhood on women's careers in the legal profession. Sadly, the bias faced by mothers in this specific trade may be replicated throughout society at large. In the words of Joan Williams, "many women never get near the glass ceiling because of the "maternal wall". ${ }^{49} \mathrm{~A}$ study published in 2012 on the wage penalty for motherhood ${ }^{50}$ calculated a wage penalty exceeding 50 per cent in the UK, which places the country in the group where penalties are highest..$^{51}$ In this respect, parallels can also be drawn between the situation in the UK and that in the US. As underlined by The Shriver Report, "Motherhood is now a greater predictor of inequality than gender in the United States of America". ${ }^{52}$ This ties in with the analysis of the situation in the English legal profession; the domino effect of the maternal wall and motherhood wage penalty ripples through the economy and society. Their intersectional dimension is made even clearer if we think that, still in the US, "while most women without children make 90 cents to a man's dollar, mothers make only 73 cents, single mothers make about 60 cents and mothers of color earn as little as 54 cents to a man's dollar". ${ }^{53}$

We are far from the complete overhaul of relations between the sexes some first-wave British feminists had in mind and the imbalance of power between men and women remains striking in the employment field and may be even more acute in the legal profession, as is hinted at by the interviews. However, the concept of maternal wall offers a framework to encompass a wide range of pervasive biases and stereotypic views that may enable courts and policy makers to target more efficiently a type of discrimination that prevents a majority of women from reaching equality with men, in the field of employment as in other aspects of life.

These questions should be openly addressed by political leaders, who often leave them to equality bodies such as the EHRC in the UK, without instilling the necessary political will. In times of austerity, those bodies are often underfunded and the budgetary cuts impact women and gender equality sharply, as was recently underlined in a report on equality between women and men in the European Union. ${ }^{54}$ According to the report, austerity policies often evolve into a reprivatisation of care and a return to traditional gender roles. For working mothers, this frequently translates into trivial day-to-day compromises: "I think on the whole, it's not only the social pressure on women [...]. It's other things, and the 'Who comes home from the office early if the children are ill?' and things like that." [Interview 15]. The words of this interviewee express in simple terms how these complex loaded questions transfer into private lives, reminding us of the validity of the famous second wave feminist slogan "the personal is political": plus ça change ...? University, where she teaches legal English. She is an alumna of the ENS de 
Cachan and was a visiting fellow at Queen Mary University Law School. She has specialised in gender, discrimination and intersectionality issues, especially in the field of sociology of law

\section{BIBLIOGRAPHIE}

Allen, Ann Taylor, Feminism and Motherhood in Western Europe, 1890-1970. The Maternal Dilemma (New York, Palgrave Macmillan, 2005).

Andronici, Justine F. and Katz, Debra S., 'Scaling the Maternal Wall', Ms Magazine, Winter 2007.

Bar barometer 2014, <https://www.barstandardsboard.org.uk/media/1599997/

bsb_barometer_report_112pp_june_13.pdf>, [last consulted 26 May 2017].

Bar Council, Family Career Breaks Advice Pack 2016, <http://www.barcouncil.org.uk/media/404121/ bar_council_tips__advice_and_resources_family_career_breaks_for_parents_and_carers_2016.pdf> [last consulted 26 May 2017].

Bar Council Guidance 2014, <http://www.barcouncil.org.uk/for-the-bar/professional-practice-andethics/equality-and-diversity-guidance/maternitypaternityparental-leave-policies-things-tothink-about/> [last consulted 26 May 2017].

Bar Standards Board, Women at the Bar - Full Report, < https://www.barstandardsboard.org.uk/ media/1773934/women_at_the_bar_-_full_report_-_final_12_07_16.pdf> [last consulted 26 May 2017].

Berger, Joseph, et al 'Status Characteristics and Social Interaction', American Sociological Review 37.3 (1972), pp. 241-55

Berrington, Ann, 'Childlessness in the UK', in Michaela Kreyenfeld and Dirk Konietzka (eds.), Childlessness in Europe: Contexts, Causes, and Consequences (Cham, Springer, 2017), pp. 57-76.

Bilge, Sirma, 'Théorisations féministes de l'intersectionnalité', Diogène 225.1 (2009), pp. 70-88.

Boyd, Ginger Ging-Dwan, 'The Girl Effect: A Neoliberal Instrumentalization of Gender Equality', Consilience: The Journal of Sustainable Development 15 (2016), pp. 146-180.

Budig, Michelle J. and England, Paula, 'The Wage Penalty for Motherhood', American Sociological Review 66.2 (2001), pp. 204-225.

Budig, Michelle J., Misra, Joya and Boeckmann, Irene, “The Motherhood Penalty in Cross-National Perspective: The Importance of Work-Family Policies and Cultural Attitudes", Social Politics 19.2 (2012), pp. 163-193.

Chittenden, Tara, (Law Society Strategic Research Unit), Career Experiences of Gay and Lesbian Solicitors (2006).

Commercial Bar Association (COMBAR), 'Pupillage, Maternity Leave and Pro Bono Work. A Survey, 2005' 
Crenshaw, Kimberlé, 'Demarginalizing the Intersection of Race and Sex: A Black Feminist Critique of Antidiscrimination Doctrine, Feminist Theory, and Antiracist Politics', University of Chicago Legal Forum (1989), pp. 139-167.

Crenshaw, Kimberlé, 'Mapping the Margins: Intersectionality, Identity Politics, and Violence Against Women of Color', Stanford Law Review 43 (1991), pp. 1241-1299.

EHRC, Research on the experiences of employers and mothers in the $21^{\text {st }}$ Century, 2014-15, <https:// www.equalityhumanrights.com/en/our-work/news/pregnancy-and-maternity-discriminationforces-thousands-new-mothers-out-their-jobs>, [last consulted 26 May 2017]

Equality Act, <http://www.legislation.gov.uk/ukpga/2010/15/section/18>, [last consulted 26 May 2017].

Fredman, Sandra, Discrimination Law (Oxford, Oxford University Press, 2002).

The Guardian, 'The law of motherhood', The Guardian, 28 April 2011. [online] http:// www.theguardian.com/law/2011/apr/28/barristers-solicitors, consulted 26 May 2017.

Guyard-Nedelec, Alexandrine, 'Ageism, Solicitors and Female Mature Entrants: An Awkward Combination', in Hazel Conley and Tessa Wright (eds), Handbook of Discrimination at Work (London, Gower Publishing, 2011), pp. 219-233.

Guyard-Nedelec, Alexandrine, “Dans quelle case rentrez-vous ?' Identité et intersectionnalité', ¿ Interrogations? online journal, n²0. Penser l'intersectionnalité, June 2015 [online], http:// www.revue-interrogations.org/Dans-quelle-case- rentrez-vous [26 May 2017].

Hancock, Ange-Marie, Intersectionality. An intellectual history (Oxford, OUP, 2016).

Héritier, Françoise, Masculin/Féminin II. Dissoudre la hiérarchie (Paris, Odile Jacob, 2012).

Higher Education statistics, <https://www.hesa.ac.uk/index.php?

option=com_datatables\&Itemid=121\&view=category\&catdex=3> [consulted 26 May 2017].

Hill Collins, Patricia and Bilge, Sirma, Intersectionality (Cambridge, UK; Malden, MA, Polity Press, 2016).

Institute of Barrister's Clerks, <http://www.ibc.org.uk/about/> [last consulted 26 May 2017]. Jordan-Zachery, Julia, 'Am I a Black Woman or a Woman Who Is Black? A Few Thoughts on the Meaning of Intersectionality', Politics \& Gender, 3. 2 (2007), pp. 254-63.

Law Commission, Aggravated, Exemplary and Restitutionary Damages (LC247, 1997), <http:// lawcommission.justice.gov.uk/publications/aggravated-exemplary-restitionary-damages.htm> [consulted 26 May 2017].

Law Society, Obstacles and Barriers to the career development of woman solicitors, Report Prepared for the Law Society by Insight Oxford Ltd., 2010, <http://www.lawsociety.org.uk/policy-campaigns/ research-trends/research-publications/obstacles-and-barriers-to-the-career-development-ofwomen-solicitors/> [last consulted 26 May 2017].

Lombardo, Emanuela, Meier, Petra and Verloo, Mieke, The Discursive Politics of Gender Equality: Stretching, Bending and Policy-Making (London, Routledge, 2009).

Mattioli, Marie-Annick, 'Le marché du travail et les femmes au Royaume-Uni: précarité de l'emploi et mères-célibataires (2000-2015)', in Florence Binard and Guyonne Leduc, Mèrescélibataires, De la malédiction au libre-choix? Regards croisés France/Grande-Bretagne (Paris, L'Harmattan, 2016), pp. 91-110. 
McGlynn, Clare, 'The Status of Women Lawyers in the United Kingdom', in Ulrike Schultz and Gisela Shaw (eds), Women in the World's Legal Profession (Oxford \& Portland (OR), Hart, 2003) pp. 139-158.

Muzio, Daniel, Brock, David M. and Suddaby, Roy, 'Professions and Institutional Change: Towards an Institutionalist Sociology of the Professions', Journal of Management Studies 50.5 (2013), pp. 699-721.

Office for National Statistics, Women in the labour market: 2013, <https://www.ons.gov.uk/ employmentandlabourmarket/peopleinwork/employmentandemployeetypes/articles/ womeninthelabourmarket/2013-09-25> [last consulted 26 May 2017].

Pew Research Center 2010 figures, <http://www.pewsocialtrends.org/2010/06/25/childlessnessup-among-all-women-down-among-women-with-advanced-degrees/> [last consulted 26 May 2017].

Phelps, Edmund, 'The Statistical Theory of Sexism and Racism', American Economic Review 62.4 (1972), pp. 659-661.

Phillips, Anne, 'What's wrong with essentialism?' Distinktion: Scandinavian journal of social theory, 11.1 (2010), pp. 47-60.

Reisz, Matthew, 'Intersectionality: 'the most exciting theory in the world", Times Higher Education, 19 May 2016, <https://www.timeshighereducation.com/news/intersectionality-most-excitingtheory-world $>$ [last consulted 26 May 2017].

Ridgeway, Cecilia, 'Gender, Status, and the Social Psychology of Expectations' in Paula England (ed.), Theory On Gender/ Feminism On Theory (Hawthorne (NY), Walter de Gruyter, 1993), pp. 175-197.

Ridgeway, Cecilia and Correll, Shelley, 'Motherhood as a Status Characteristic', Journal of Social Issues 60.4 (2004), pp. 683-700.

Ridgeway, Cecilia and Correll, Shelley, 'Expectation States Theory' in John Delamater (ed.), Handbook of Social Psychology, (Springer, 2006) pp. 29-51.

Rowe-Kinkbeiner, Kristin, 'Breaking Through the Maternal Wall: The Time is Now', The Shriver Report, $1^{\text {st }}$ April 2014, <http://shriverreport.org/breaking-through-the-maternal-wall-the-timeis-now-kristin-rowe-finkbeiner/> [last consulted 26 May 2017].

Shields, Stephanie A., 'Gender: An Intersectionality Perspective', Sex Roles 59 (2008), pp. 301-311.

Siân Heard \& Fellows v Sinclair Roche \& Temperley. Cases 2201499/02 \& 2201637/02, London Central Employment Tribunal, 2004.

Sommerlad, Hilary, 'Women Solicitors in a Fractured Profession: Intersections of Gender and Professionalism in England and Wales', International Journal of the Legal Profession 9.3 (2002), pp. 213-234.

Sommerlad, Hilary, "What Are You Doing Here? You Should Be Working in a Hair Salon or Something': Outsider Status and Professional Socialization in the Solicitors' Profession', Web JCLI 2 (2008), < http://letr.org.uk/references/storage/QT64TQ6C/sommerlad2.html> [last consulted 26 May 2017].

Sommerlad, Hilary, “A pit to put women in': professionalism, work intensification, sexualisation and work-life balance in the legal profession in England and Wales', International Journal of the Legal Profession 23.1 (2016), pp. 61-82. 
Swiss, Deborah and Walker, Judith, Women and the Work/Family Dilemma: How Today's Professional Women are Confronting the Maternal Wall (New York, John Wiley \& Sons, 1993).

Thornton, Margaret, 'Work/life or work/work? Corporate legal practice in the twenty-first century', International Journal of the Legal Profession 23.1 (2016), pp. 13-39.

Tiedje, Linda, 'Processes of Change in Work/Home Incompatibilities: Employed Mothers 19861999', Journal of Social Issues 60.4 (2004), pp. 787-800.

Urtasun, Ernest (Rapporteur), Committee on Women's Rights and Gender Equality, 'Report on equality between women and men in the European Union in 2014-2015' (2016/2249(INI)), 23 February 2017, <http://www.europarl.europa.eu/sides/getDoc.do?pubRef=\%2F\%2FEP\%2F\%2FTEXT\%2BREPORT\%2BA8-2017-0046\%2B0\%2BDOC\%2BXML\%2BV0\%2F\%2FEN\&language=GA\#title2> [last consulted 26 May 2017].

Verkaik, Robert, 'Law firm settles 'homophobia' discrimination case', The Independent, 21 August 2007, <http://www.independent.co.uk/news/uk/crime/law-firm-settles-homophobiadiscrimination-case-462391.html [06/09/10]> [last consulted 26 May 2017].

Webley, Lisa and Duff, Liz, 'Women Solicitors as a Barometer for Problems within the Legal Profession - Time to Put Values before Profit?', Journal of Law and Society 34.3 (2007), pp. 374-402.

Williams, Joan C., 'Hitting the Maternal Wall', Academe 90.6 (2004), pp. 16-20.

Williams, Joan C. and Westfall, Elisabeth S., 'Deconstructing the Maternal Wall: Strategies for Vindicating the Civil Rights of 'Carers' in the Workplace', Duke Journal of Gender Law \& Policy 13 (2006), pp. 31-53.

Work and Family Researchers Network, <https://workfamily.sas.upenn.edu/glossary/m/ maternal-wall-definitions> [consulted 26 May 2017].

\section{NOTES}

1. Deborah Swiss and Judith Walker, Women and the Work/Family Dilemma: How Today's Professional Women are Confronting the Maternal Wall (New York, John Wiley \& Sons, 1993)

2. Joan C. Williams, "Hitting the Maternal Wall", Academe 90.6 (2004), p. 18.

3. See the maternal wall definition provided by the Work and Family Researchers Network, at https://workfamily.sas.upenn.edu/glossary/m/maternal-wall-definitions, consulted 26 May 2017.

4. Justine F. Andronici and Debra S. Katz, "Scaling the Maternal Wall”, Ms Magazine, Winter 2007.

5. Ann Taylor Allen, Feminism and Motherhood in Western Europe, 1890-1970. The Maternal Dilemma (New York, Palgrave Macmillan, 2005), p. 8.

6. Françoise Héritier, Masculin/Féminin II. Dissoudre la hiérarchie (Paris, Odile Jacob, 2012).

7. Ann Berrington, "Childlessness in the UK", in Michaela Kreyenfeld and Dirk Konietzka (eds.), Childlessness in Europe: Contexts, Causes, and Consequences (Cham, Springer, 2017), p. 57. Interestingly, the vast majority of statistics, articles and research papers use the terms 'childless' and 'childnessness', with negative suffixes, to refer to this social fact.

8. Pew Research Center 2010 figures, http://www.pewsocialtrends.org/2010/06/25/ childlessness-up-among-all-women-down-among-women-with-advanced-degrees/, last consulted 26 May 2017.

9. Ann Berrington, “Childlessness in the UK", p. 70. 
10. Office for National Statistics, Women in the labour market: 2013. See full report at https:// www.ons.gov.uk/employmentandlabourmarket/peopleinwork/employmentandemployeetypes/ articles/womeninthelabourmarket/2013-09-25, last consulted 26 May 2017.

11. The fieldwork this article partly relies on included 19 sociological, semi-conducted interviews with women solicitors, barristers, judges and equality officers and produced qualitative data on identity-related issues within the context of the English legal profession. The profile of the interviewees covered the whole range of the different branches of the English legal profession (apart from Legal Executives) and was as follows: 9 solicitors (including 2 partners and 2 law graduates looking for a training contract), 6 barristers (including a Queen's Counsel), 2 judges (a district judge and a senior judge), an equality officer for the Bar Council and a chambers' administrator. The qualitative data was analysed by using discourse analysis that focused on discursive themes across interview data. So as to preserve the interviewees' anonymity and according to the rules set up by Queen Mary University, where the fieldwork was designed and conducted, based on the Data Protection Act 1998, the interviews are not followed by a descriptor including their age, ethnicity, sexual orientation, etc. This also fits in with the holistic perspective favoured by intersectional studies and reduces the risk of an essentialist approach. For more details on the interviews, see Alexandrine Guyard-Nedelec, "Dans quelle case rentrezvous?' Identité et intersectionnalité', i Interrogations ? online journal, n²0. Penser l'intersectionnalité, June 2015.

12. These patterns apply across the board, as is shown by the EHRC, Research on the experiences of employers and mothers in the $21^{\text {st }}$ Century, 2014-15, https://www.equalityhumanrights.com/en/ourwork/news/pregnancy-and-maternity-discrimination-forces-thousands-new-mothers-out-theirjobs, last consulted 26 May 2017; their 2016 digital campaign \#PowertotheBump further demonstrates that this is a burning societal issue.

13. Kimberlé Crenshaw, "Demarginalizing the Intersection of Race and Sex: A Black Feminist Critique of Antidiscrimination Doctrine, Feminist Theory, and Antiracist Politics", University of Chicago Legal Forum (1989), pp. 139-167 and "Mapping the Margins: Intersectionality, Identity Politics, and Violence Against Women of Color", Stanford Law Review 43 (1991), pp. 1241-1299.

14. See Sirma Bilge, "Théorisations féministes de l'intersectionnalité », Diogène 225.1 (2009), pp. 70-88. Recent publications include Patricia Hill Collins and Sirma Bilge, Intersectionality (Cambridge, UK; Malden, MA, Polity Press, 2016) and Ange-Marie Hancock, Intersectionality. An intellectual history (Oxford, OUP, 2016). Matthew Reisz's article in the Times Higher Education (19 May 2016) illustrates the spreading of the theory/concept to a wider public: "Intersectionality: "the most exciting theory in the world".

15. Although essentialism should not be rejected outright, as may be linked to the very process of thought, it is often associated with over-generalisation, disproportionate normative weight, biological determinism and the naturalising of socially and historically generated difference. For a critique of essentialism and its different meanings, see Anne Phillips, "What's wrong with essentialism?" Distinktion: Scandinavian journal of social theory, 11.1 (2010), pp. 47-60.

16. See the Bar barometer 2014, https://www.barstandardsboard.org.uk/media/1599997/ bsb_barometer_report_112pp_june_13.pdf, last consulted 26 May 2017, and Higher Education statistics, https://www.hesa.ac.uk/index.php? option=com_datatables\&Itemid=121\&view=category\&catdex=3, last consulted 26 May 2017.

17. Clare McGlynn, "The Status of Women Lawyers in the United Kingdom", in Ulrike Schultz and Gisela Shaw (eds), Women in the World's Legal Profession (Oxford \& Portland (OR), Hart, 2003), p.145.

18. For instance, in the barrister's branch of the profession, women made up $48 \%$ of those called to the Bar in 1998 (see Clare McGlynn, Ibid.., p.153); 52.2\% in 2008 (Bar Council, "Annual Statistics as at December 2008"); and 48.8\% in 2014-15 (Bar Standards Board, "Called to the Bar Statistics"). 19. http://www.legislation.gov.uk/ukpga/2010/15/section/18, last consulted 26 May 2017. 
20. For more detail on the comparator issue, see Sandra Fredman, Discrimination Law (Oxford, Oxford University Press, 2002) pp. 99-100.

21. https://www.gov.uk/maternity-pay-leave/overview, last consulted 26 May 2017.

22. Edmund Phelps, "The Statistical Theory of Sexism and Racism", American Economic Review 62.4 (1972), p. 659.

23. 2014 Bar Council Guidance. http://www.barcouncil.org.uk/for-the-bar/professional-practiceand-ethics/equality-and-diversity-guidance/maternitypaternityparental-leave-policies-thingsto-think-about/, last consulted 26 May 2017.

24. 2016 version of the pack at http://www.barcouncil.org.uk/media/404121/ bar_council_tips__advice_and_resources_family_career_breaks_for_parents_and_carers_2016.pdf, last consulted 26 May 2017.

25. The BSB carried out research among women at the Bar in 2016 to improve their knowledge of the implementation and effectiveness of the Rules and to explore issues which may be contributing to a lack of retention, https://www.barstandardsboard.org.uk/media/1773934/ women_at_the_bar_-_full_report_-_final_12_07_16.pdf, last consulted 26 May 2017.

26. As mentioned in the survey undertaken by the Commercial Bar Association (COMBAR), "Pupillage, Maternity Leave and Pro Bono Work. A Survey, 2005".

27. Law Society, "Obstacles and Barriers to the career development of woman solicitors", Report Prepared for the Law Society by Insight Oxford Ltd., 2010, p. 9. The issues at stake around flexibility in the legal profession differ from large-scale analyses of part-time work in Britain for instance. Indeed, these analyses often stress the fact that part-time work is frequently imposed on women, which leads to lower wages etc., as is underlined by Marie-Annick Mattioli, "Le marché du travail et les femmes au Royaume-Uni: précarité de l'emploi et mères-célibataires (2000-2015)", in Florence Binard and Guyonne Leduc, Mères-célibataires, De la malédiction au librechoix ? Regards croisés France/Grande-Bretagne (Paris, L'Harmattan, 2016), pp. 91-110.

28. Emanuela Lombardo, Petra Meier, Mieke Verloo, The Discursive Politics of Gender Equality: Stretching, Bending and Policy-Making, (London, Routledge, 2009), esp. p. 125. A similar analysis of the pervasive effect of the business case for gender equality has developed in the field of development, both at academic and institutional level. See for instance Ginger Ging-Dwan Boyd, "The Girl Effect: A Neoliberal Instrumentalization of Gender Equality", Consilience: The Journal of Sustainable Development 15 (2016), pp. 146-180.

29. Hilary Sommerlad, "Women Solicitors in a Fractured Profession: Intersections of Gender and Professionalism in England and Wales”, International Journal of the Legal Profession 9.3 (2002), p. 215.

30. Daniel Muzio, David M. Brock and Roy Suddaby, "Professions and Institutional Change: Towards an Institutionalist Sociology of the Professions", Journal of Management Studies 50.5 (2013) pp. 699-721.

31. Law Society, "Obstacles and Barriers to the career development of woman solicitors", p. 8.

32. See in particular “'A pit to put women in': professionalism, work intensification, sexualisation and work-life balance in the legal profession in England and Wales", International Journal of the Legal Profession 23.1 (2016), pp. 61-82.

33. Margaret Thornton, "Work/life or work/work? Corporate legal practice in the twenty-first century" International Journal of the Legal Profession 23.1 (2016), pp. 13-39.

34. Linda Tiedje, 2004, "Processes of Change in Work/Home Incompatibilities: Employed Mothers 1986-1999", Journal of Social Issues 60.4 (2004), p. 788.

35. Cecilia Ridgeway and Shelley Correll, "Motherhood as a Status Characteristic", Journal of Social Issues 60.4 (2004), p. 687.

36. The importance of applying an intersectional perspective to gender studies is put forward in a very intelligible way by Stephanie A. Shields in "Gender: An Intersectionality Perspective", Sex Roles 59 (2008), pp. 301-311. 
37. The theory was introduced in the 1970s by Joseph Berger et al. ("Status characteristics and social interaction", American Sociological Review 37.3 (1972), pp. 241-55) and developed in the 2000s by Cecilia Ridgeway and Shelley Correll ("Expectation States Theory" in John Delamater (ed.), Handbook of Social Psychology, (Springer, 2006) pp. 29-51). Expectation states theory seeks to explain the emergence of status hierarchies in situations where actors are oriented towards the accomplishment of a collective goal or task.

38. Cecilia Ridgeway, "Gender, Status, and the Social Psychology of Expectations" in Paula England (ed.), Theory On Gender/ Feminism On Theory, (Hawthorne (NY), Walter de Gruyter, 1993), pp. 175-197.

39. Cecilia Ridgeway and Shelley Correll, "Motherhood as a Status Characteristic", p. 697.

40. Hilary Sommerlad, "What Are You Doing Here? You Should Be Working in a Hair Salon or Something': Outsider Status and Professional Socialization in the Solicitors' Profession", Web JCLI 2 (2008). p. 12.

41. Alexandrine Guyard-Nedelec, "Ageism, Solicitors and Female Mature Entrants: An Awkward Combination", in Hazel Conley and Tessa Wright (eds), Handbook of Discrimination at Work (London, Gower Publishing, 2011), pp. 219-233.

42. Hilary Sommerlad, "Women Solicitors in a Fractured Profession: Intersections of Gender and Professionalism in England and Wales", International Journal of the Legal Profession 9.3 (2002), pp. 217-18.

43. Statistics from the Institute of Barrister's Clerks website, http://www.ibc.org.uk/about/, last consulted 26 May 2017.

44. Lisa Webley and Liz Duff, "Women Solicitors as a Barometer for Problems within the Legal Profession - Time to Put Values before Profit?", Journal of Law and Society 34.3 (2007), p. 375.

45. "The law of motherhood", The Guardian, 28 April 2011.

46. All quotes and figures from Siân Heard \& Fellows $v$ Sinclair Roche \& Temperley. Cases 2201499/02 \& 2201637/02, London Central Employment Tribunal, 2004.

47. Interview 18. A similar remark was made concerning LGB lawyers: when they felt discriminated against, almost none of her interviewees engaged in a lawsuit (Chittenden, Tara (Law Society Strategic Research Unit), Career Experiences of Gay and Lesbian Solicitors, 2006, pp. 58-59). Robert Verkaik illustrated the phenomenon in The Independent, with his article 'Law firm settles 'homophobia' discrimination case' (21 August 2007).

48. Metaphor borrowed from Julia Jordan-Zachery, “Am I a Black Woman or a Woman Who Is Black? A Few Thoughts on the Meaning of Intersectionality", Politics \& Gender, 3. 2 (2007), pp. 254-63.

49. Joan C. Williams, "Hitting the Maternal Wall", p. 17.

50. Michelle J. Budig and Paula England, "The Wage Penalty for Motherhood", American Sociological Review 66.2 (2001), pp. 204-225.

51. Michelle J. Budig, Joya Misra and Irene Boeckmann, "The Motherhood Penalty in CrossNational Perspective: The Importance of Work-Family Policies and Cultural Attitudes", Social Politics 19.2 (2012), p. 175.

52. Kristin, Rowe-Kinkbeiner, "Breaking Through the Maternal Wall: The Time is Now", The Shriver Report, $1^{\text {st }}$ April 2014.

53. Ibid.

54. Ernest Urtasun (Rapporteur), Committee on Women's Rights and Gender Equality, 'Report on equality between women and men in the European Union in 2014-2015' (2016/2249(INI)), 23 February 2017. 


\section{RÉSUMÉS}

En dépit d'évolutions non négligeables depuis leur entrée dans les professions juridiques (1922, Angleterre/pays de Galles), nul ne peut ignorer que les femmes gravissent les échelons plus lentement, sont souvent cantonnées à certains domaines du droit et, par conséquent, ne représentent qu'une faible proportion de la magistrature. Pourtant, les statistiques des écoles de droit, et la parité observée en début de carrière depuis une vingtaine d'années, tendent à saper l'argument selon lequel les femmes perceraient petit à petit, tout n'étant qu'une question de temps : plus ça change, plus c'est la même chose?

Cet article offre une étude de cas centrée sur l'égalité femmes-hommes au sein des professions juridiques anglo-galloises, qui souligne le poids de la maternité dans la lente transformation des rôles selon le sexe dans les professions dites libérales. L'auteure y met en œuvre le concept de mur maternel. Ce concept, au-delà des écarts salariaux, s'intéresse à d'autres impacts de la maternité en matière de carrière et de discriminations; il apporte un éclairage singulier à des témoignage d'avocates déclarant en entretien qu'il n'y avait pas de discrimination fondée sur le sexe dans leur profession, mais que celles fondées sur la maternité étaient très fréquentes. Sur le plan théorique, cette dissociation mène l'auteure à revendiquer la construction de la maternité en tant que facette identitaire intersectionnelle afin d'éviter le double écueil de la biologisation et de l'essentialisme. Sur le plan pratique, les horaires, les contraintes spécifiques d'emploi du temps, le rôle des clerks au sein des cabinets, tous ces éléments contribuent à une perpétuation du patriarcat.

S'appuyant sur une enquête de terrain ainsi que sur la littérature existante, l'article tente de démontrer que, malgré l'existence d'un cadre légal adéquat et la mise en œuvre de mesures internes pour l'égalité dans un secteur en pleine expansion, c'est le déséquilibre qui continue de caractériser l'accès aux positions de pouvoir entre hommes et femmes avocat.e.s (et par conséquent chez les juges, ces professions étant intégrées dans la tradition de common law).

In spite of significant change since their entry into the legal profession in 1922 in England and Wales, the slower progression of women on the professional ladder, their relative confinement to certain areas of the law and, consequently, the small proportion they account for in the senior judiciary remain blatant. Yet, undermining the 'trickle-up' argument, women now outnumber men among law students, achieve better academic results on the whole, and have made up around $50 \%$ of the profession at entry level for about twenty years: plus ça change...?

The article presents a case study focusing on gender equality issues in the legal profession in England and Wales that underlines the specific weight of motherhood in the slow transformation of women's role vis-à-vis that of men. The author implements the concept of maternal wall (Swiss \& Walker, 1993), which looks at the pay gap but also at other impacts of maternity in terms of career and discrimination. Applied to the English legal profession, this sheds light on the testimonies of women barristers and solicitors who have often said they believed there was no sex discrimination, but that discrimination on the grounds of maternity was rife. On a theoretical level, this leads the author to argue for the construction of maternity and motherhood as intersectional identity facets, so as to avoid the two-fold pitfall of naturalization and essentialism. On a practical level, the hours, the specific timetable constraints, the role of clerks in chambers, etc., all contribute to a perpetuation of patriarchy in the profession.

By relying on examples derived from fieldwork as well as the existing literature on the subject, the paper aims to show that in spite of an accurate statutory frame and the enforcement of internal gender equality policies in a rapidly expanding sector, the overall imbalance of power between men and women lawyers (and therefore judges) has not shifted. 
INDEX

Mots-clés : genre, intersectionnalité, professions juridiques, mur maternel, ségrégation professionnelle, femmes

Keywords : gender, intersectionality, legal profession, maternal wall, occupational segregation, women

\section{AUTEUR}

\section{ALEXANDRINE GUYARD-NEDELEC}

ISJPS, Université Paris 1 - Panthéon-Sorbonne 